\title{
Outsourcing and organizational change : an employee perspective
}

Citation for published version (APA):

Roe, R. A., Smeelen, M., \& Hoefeld, C. (2005). Outsourcing and organizational change : an employee perspective. METEOR, Maastricht University School of Business and Economics. METEOR Research Memorandum No. 045 https://doi.org/10.26481/umamet.2005045

Document status and date:

Published: 01/01/2005

DOI:

10.26481/umamet.2005045

Document Version:

Publisher's PDF, also known as Version of record

\section{Please check the document version of this publication:}

- A submitted manuscript is the version of the article upon submission and before peer-review. There can be important differences between the submitted version and the official published version of record.

People interested in the research are advised to contact the author for the final version of the publication, or visit the DOI to the publisher's website.

- The final author version and the galley proof are versions of the publication after peer review.

- The final published version features the final layout of the paper including the volume, issue and page numbers.

Link to publication

\footnotetext{
General rights rights.

- You may freely distribute the URL identifying the publication in the public portal. please follow below link for the End User Agreement:

www.umlib.nl/taverne-license

Take down policy

If you believe that this document breaches copyright please contact us at:

repository@maastrichtuniversity.nl

providing details and we will investigate your claim.
}

Copyright and moral rights for the publications made accessible in the public portal are retained by the authors and/or other copyright owners and it is a condition of accessing publications that users recognise and abide by the legal requirements associated with these

- Users may download and print one copy of any publication from the public portal for the purpose of private study or research.

- You may not further distribute the material or use it for any profit-making activity or commercial gain

If the publication is distributed under the terms of Article $25 \mathrm{fa}$ of the Dutch Copyright Act, indicated by the "Taverne" license above, 
Running head: Outsourcing \& Organizational Change

\title{
Outsourcing and Organizational Change
}

An employee perspective

\author{
Robert A. Roe * \\ Mariska Smeelen ** \\ Carola Hoefeld *
}

* Department of Organization and Strategy, Universiteit Maastricht, the Netherlands

** Department Work \& Organizational psychology, Radboud University Nijmegen

Address correspondence to:

Prof.dr. Robert A. Roe

Universiteit Maastricht, Faculty of Economics and Business Administration

P.O. Box 616, 6200 MD Maastricht, The Netherlands

Phone: +31 433884985

Fax: $\quad+31433884893$

E-mail: r.roe@os.unimaas.nl 


\begin{abstract}
Outsourcing seems to have become the new trend in organizational strategy. In outsourcing, part of the organization's production or service process is discontinued and transferred to another party, along with personnel and other resources. Although the potential economic benefits of outsourcing are thought to be considerable, a growing number of evaluation studies show disappointing outcomes. Cost savings tend to be less than expected and quality sometimes declines. A reason for these outcomes may be that - just like with downsizing and mergers-acquisitions in earlier days - managers tend to focus almost exclusively on economic aspects, ignoring the human and social impacts. More specifically, one might explain unsatisfactory economic results from a failure to consider the change implications of outsourcing. This paper analyzes the nature of the organizational change implied in outsourcing, comparing it to mergersacquisitions and downsizing. Next, it identifies some critical aspects of the transition management process which, when dealt with effectively, may enhance the success of outsourcing. The theoretical analysis is contrasted with findings from an empirical study on outsourcing in the Netherlands. In interviews with 11 experts and 10 workers on three phases of outsourcing, 70 aspects of (un)successful transition management were identified. Next, 36 employees involved in outsourcing rated the importance of these aspects and indicated their presence during the outsourcing process. Discrepancy ratings, showing which aspects of transition management received insufficient attention, confirm the results of the theoretical analysis. This underlines the importance of organizational change when implementing outsourcing.
\end{abstract}




\section{Outsourcing and Organizational Change}

Outsourcing, or the contracting out of non-core business activities (e.g. Hellriegel, Jackson, \& Slocum, 2002; Lankford \& Parsa, 1999), is one of the most popular trends in organizational strategy of the last decade (Logan, Faught, \& Ganster, 2004). The key idea is that organizations can free-up resources involved in support functions in order to improve the performance of core functions (Elmuti, Kathawala, \& Monippalil, 1998). The improved performance resulting from this is expected to outweigh the loss of control. There are various forms of outsourcing. For instance, employees are terminated before activities are transferred to an external service provider, an in-house department is transformed into an independent company that subsequently provides services to its "mother"-company, or both activities and employees are transferred to a service provider (Logan et al., 2004). We will focus on the last form, which implies that the employees of an outsourcing organization are transferred to an organization (called outsourcing provider) and remain subsequently involved in delivering services to their former employer, at least for some period of time.

Outsourcing has been applied in sectors such as manufacturing, cleaning, security, catering, transportation, maintenance engineering, finance and accounting, personnel administration, travel services, and information and communication technology (ICT). During the last decade, the emphasis shifted towards the ICT sector, with $40 \%$ of all outsourcing contracts in 1998 (Elmuti et al., 1998). As a consequence this sector has received most emphasis in the recent literature, too. Our own study is also related to ICT.

\section{Outsourcing in as organizational strategy}

Most of the academic literature has looked upon outsourcing (OS) from a strategic perspective (Elmuti \& Kathawala, 2000; Gilley, Greer, \& Rasheed, 2004; Gupta \& Gupta, 
1992; Lepak \& Snell, 1999). This means that the emphasis is on the aimed-for objectives and the outcomes obtained. A first objective of OS is improving financial performance, mainly through cutting costs. The argument is that outside firms specializing in support functions can work cheaper because they benefit from economies of scale (Gupta \& Gupta, 1992), offer upto-date expert knowledge (Greer, Youngblood, \& Gray, 1999), and apply the latest new technologies (Due, 1992). A study by Elmuti \& Kathawala (2000) based on data from 620 US firms, ranging in size from less than 500 employees up to 50,000 employees, found that $69 \%$ of the firms engaged in outsourcing obtained significant cost savings and increased performance. However, cost savings may be limited, incidental and well below the $20 \%$ claimed by consultancies (e.g. Benson \& Littler, 2002); cost raises have also been reported (Walker \& Walker, 2000). A second objective is enhancing operational flexibility. Service contracts with outside suppliers offer the opportunity for purchasing services according to variable needs, which can also save costs (Due, 1992). A third objective, especially relevant for technology intensive business activities is to avoid replacement cost for obsolete technical equipment (Gupta \& Gupta, 1992). Other objectives seem to play a role as well. It has been argued that public organizations as well as business firms copy each other in order to convey the image of modern management to the outside world (Walker \& Walker, 2000), which fits into the institutional view on organizations (DiMaggio \& Powell, 1983). This view is supported by the fact that outsourcing does not always achieve its objectives (Doig, Ritter, Speckhals, \& Woolson, 2001).

The impacts of outsourcing are not limited to the economic domain. There are also organizational implications, such as loss of control over how an outsourced activity is carried out or a service is delivered (Elmuti et al., 1998; Lankford \& Parsa, 1999) including a loss of property rights (Loh \& Venkatraman, 1992). The organization may become dependent on the 
external service provider and thereby lose strategic flexibility (Kakabadse \& Kakabadse, 2003).

Impacts of outsourcing on the service provider have received much less attention than that on the outsourcer. Although outsourcing is generally depicted as a win-win strategy, from which both the outsourcer and the service provider profit, this may not always be the case. The conditions of the service contract, and especially the guarantees given to the employees regarding employment, career and pay may limit the benefits for some period of time. For the service provider it is crucially important that the OS process goes well in order to ensure that employees are committed and motivated to perform. Unwillingness to change, distrust and lack of commitment may seriously undermine the feasibility and success of the outsourcing operation.

\section{Outsourcing and human resources}

Thus far, limited attention has been paid to the human resource aspects of outsourcing and the impacts on employees (Benson, 1998; Khosrowpour \& Subramanian, 1996; Logan et al., 2004). Outsourcing can have a range of effects on individual employees who are directly involved in it. First, outsourcing is readily perceived as a breach of the psychological contract with the original employer (cf. Coyle Shapiro \& Kessler, 2002) and can therefore lead to a drop in morale. Second, it evokes job insecurity and concern about a deterioration of working conditions (e.g. relating to place of work, duration of commuting etc.). Although these aspects may be covered in the outsourcing contract, it also happens that not all employees are hired by the new employer or remain on the pay role for a longer time (Due, 1992) which leaves tangible risks for some employees. Third, employees may consider outsourcing plans "as an underestimation of their talents and credibility", which may lead valuable staff to quit

the firm (Gupta \& Gupta, 1992). Fourth, employees may experience a loss of identity as they loose their original position and the link with their first employer; this may impede their 
integration with the new employer (Logan et al., 2004). Fifth, as a result of all this, employees may show a decline in trust and commitment (cf. Benson, 1998). These kinds of effects and the resources needed to address them add to the real costs of outsourcing (Due, 1992; Kakabadse \& Kakabadse, 2003).

Apart from effects on the employees that are directly involved because their work is being outsourced, there may also be indirect effects on other employees. For instance, partial outsourcing, which means that certain activities are retained at the outsourcing firm, implies that the remaining employees will have less opportunity to gain broad experience in their field and have less career chances (Greer et al., 1999). Depending on the way in which the OS process is managed, survivors may also respond with perceptions of uncertainty, distrust and reduced commitment, similar to what is known from the literature on downsizing (Allen, Freeman, Russell, Reizenstein, \& Rentz, 2001; Mishra \& Spreitzer, 1998). On the side of the service provider there may be effects as well. For instance, Pearce (1993) found that regular employees tended to loose trust in their employer when the latter hired contract workers from outside. Both direct and indirect human impacts of OS are important and deserve research attention in their own right, but it is also important to consider them because they can complicate the outsourcing process and undermine its outcomes. Better qualified employees may decide not to stay on board and look for another job, the transition process may be hampered by resistance to change, and shifts in attitudes may negatively affect productivity (Logan et al., 2004).

Not all effects of outsourcing on employees are negative, though. Outsourcing also brings new training and career opportunities in a specialized environment. Employees who could not climb the career ladder because of a lack of positions in their domain of expertise, can have a much better chance within a specialized firm. Evidence for this was found in a study in the ICT-sector by Pinnington and Woolcock (1997) and in a case study on 
employees of a local authority in charge of housing benefits and the collection of council tax (Kessler, Coyle-Shapiro, \& Purcell, 1999). Moreover, after moving to a specialized firm, experts who used to work in non-core departments may earn a higher salary; at least this has been observed in the ICT sector (Gupta \& Gupta, 1992).

The limited evidence available in the literature shows a mixed picture, with mainly negative and some positive consequences. As the outcomes seem to depend on the way in which the outsourcing process was handled (Kessler et al., 1999), it is worthwhile to take a closer look at how OS is carried out, and to analyze it from the point of view of organizational change.

\section{Outsourcing as organizational change process}

The impact of a decision to outsource a certain business activity on the employees and the organization of which they are part is brought about by the implementation process. Outsourcing, like other strategies, can only be expected to achieve its objectives through a successful organizational change process. Next to case studies (e.g. Kessler et al., 1999), the literature provides models and scenarios that describe the phases organizations should go through when outsourcing, as well as specific activities (e.g. Lankford \& Parsa, 1999; Van der Zee, 1999). Descriptions such as these reveal an obvious difference compared to classical organizational change where structures and/or processes in a single organization are modified without major adjustments in the workforce. Outsourcing is a process that runs through two organizations and it forces employees to leave the first one and become part of the second one.

There is not much literature on how to manage the change processes of this specific kind. Some lessons may be drawn from publications on organizational changes in downsizing and mergers, which emphasize the need for early and open communication, the value of supporting individual employees in coping with emotions and concerns, and the importance 
of fairness (Dempsey \& McKevitt, 2001; Gutknecht \& Keys, 1993; Legare, 1998). However, it should be kept in mind that downsizing is a more dramatic event from the perspective of the employee as the contract unexpectedly ends without any view of alternative employment. Mergers tend to be less incisive because the employment is generally maintained, and job content, work contacts and work location remain unaffected. See Table 1 for a comparison of differences between outsourcing, mergers and downsizing regarding the content of the changes.

Table 1: Facets of Change in Outsourcing, Mergers and Downsizing

\begin{tabular}{lccc}
\hline \multicolumn{1}{c}{ Changes } & Outsourcing & Merger & Downsizing \\
Forced termination & Yes & No & Yes \\
Employer & Yes & Yes & \\
Salary \& fringe benefits & No & No $(\rightarrow$ Yes $)$ \\
Career & Yes & No $(\rightarrow$ Yes $)$ \\
Job content & No $(\rightarrow$ Yes $)$ & No \\
Work methods & Yes & No \\
Work contacts & Yes & No \\
Work place & No $(\rightarrow$ Yes $)$ & No $(\rightarrow$ Yes $)$ \\
Culture & Yes & Yes \\
\hline
\end{tabular}

The general literature on organizational change (e.g. Carnal, 1990; Cummings \& Huse, 1989; Cummings \& Worley, 2001; Dawson, 1994) provides some insights into factors enabling successful change that may also operate in the case of outsourcing. Among them are: (1) top management support, as to underline the importance of the change, give direction, legitimize actions of lower management, facilitate access to resources, help to align organizational processes etc.; (2) open communication with employees at an early stage of 
the process, in order to create awareness of the necessity of change, establish an image of the aimed-for goal and the planned route towards that goal, the implications for work routines and consequences for individuals; (3) opportunity for participation of employees to gain their involvement, use their knowledge, and avoid resistance to change; (4) attention and support for the individual. Approaches from which such factors are lacking are likely to produce uncertainty, insecurity and resistance to change. Cummings \& Worley (2001) also emphasize the benefits of support by professional change agents.

It seems that a number of aspects of outsourcing operate against applying this type of approach. First, outsourcing involves multiple parties, i.e. the outsourcing organization and the service provider, and it is difficult to inform and treat all employees in a consistent way. Second, organizations that opt for outsourcing tend to be relatively inexperienced and lack the professional expertise to deal with the complexities of outsourcing, especially those related to human resources. Since outsourcing is a relatively rare event that involves only a particular non-core segment of the organization, there is not much opportunity for learning and avoiding mistakes. Third, the strong focus on economic objectives leads to an overemphasis on "hard" financial and legal aspects at the expense of "soft" social aspects. Fourth, like with other strategic decisions, the decision and implementation process is under time pressure and is partly conducted in a mode of secrecy, which hampers open communication and involvement. However, there is no published evidence on organizational change in outsourcing which demonstrates these effects.

\section{Critical facets of organizational change}

Since the critical facets of organizational change in the case of outsourcing are unknown, an exploratory study was undertaken with the aim of identifying them. The study consisted of two parts. In part I interviews with experts and people involved in an actual outsourcing project were conducted and used to generate a checklist containing facets of organizational 
change that were considered to be particularly relevant for outsourcing ${ }^{1}$. This checklist was used in part II of the study, which examined perceptions of actual change processes by employees whose work was being outsourced. The two parts of the study and their findings will be summarized below.

Both parts of the study are based on an a priori segmentation of the outsourcing process into three phases, which we designate as Pre Phase, Transition Phase and Post Phase (See (Figure 1). While scenarios of outsourcing written from a managerial point of view typically distinguish more phases (Van der Zee et al., 1997), a division of the process in terms of these three phases makes more sense from the employees perspective.

\section{Part I: Development of a checklist}

In order to identify relevant aspects of OS, interviews were conducted with 10 experts on outsourcing (consultants as well as top-managers) and 11 employees who had been involved in outsourcing projects. The focus was on best and worst practices and on personal experiences during the process of change. Human resource facets were extracted from the interview scripts and incorporated in a checklist that covered the three phases of the outsourcing project distinguished above. The checklist was structured into four sections, each covering certain facets of the organizational change process, i.e. information, support, procedure and after-care. Within each section one group of items related to activities of the outsourcing firm (A) while another, similar group of items related to activities of the service providing firm (B). A few general; items pertaining to both firms were added. Table 2 gives an overview of the composition of the checklist. It also indicates the three phases of the OS process.

\footnotetext{
${ }^{1}$ This part of the research was conducted by M. Smeelen and O. Solinger under supervision of the first author.
} 
Table 2: Facets of Change in Outsourcing, Mergers and Downsizing

\begin{tabular}{|l|c|c|}
\hline Section & \# of items & Phases \\
\hline Information & & \\
A & 13 & I - II \\
B & 15 & II - III \\
\hline Personal support & 1 & I - II - III \\
General & 9 & I - II \\
A & 6 & II - III \\
B & & \\
\hline Procedure & 6 & I - II - III \\
General & 3 & I - II \\
A & 3 & II - III \\
B & & \\
\hline Aftercare & 1 & III \\
A & 13 & III \\
B & &
\end{tabular}

\section{Part II: Employee perceptions}

Design. In the second part of the study, employees involved in OS projects in the ICT-sector were asked to answer two general questions about the items in the checklist, i.e. (1) whether they found the facets important, and (2) whether they had experienced the facet in the outsourcing project they were or had been involved in. The OS projects were chosen in such a way that some employees were at the Pre Phase and others at the Post Phase at the time of collecting the data (2002). Subjects were asked to address all relevant parts of the checklist. That is, all subjects answered questions relating to the phase they were currently in, but subjects in the Transition Phase were supposed to also answer questions about the Pre Phase and subjects in the Post Phase to also answer questions about the Transition and the Pre Phases (see Figure 1). Given the structure of the checklist all subjects would respond to items regarding the outsourcing firm (A) and the service providing firm (B), wherever possible. 


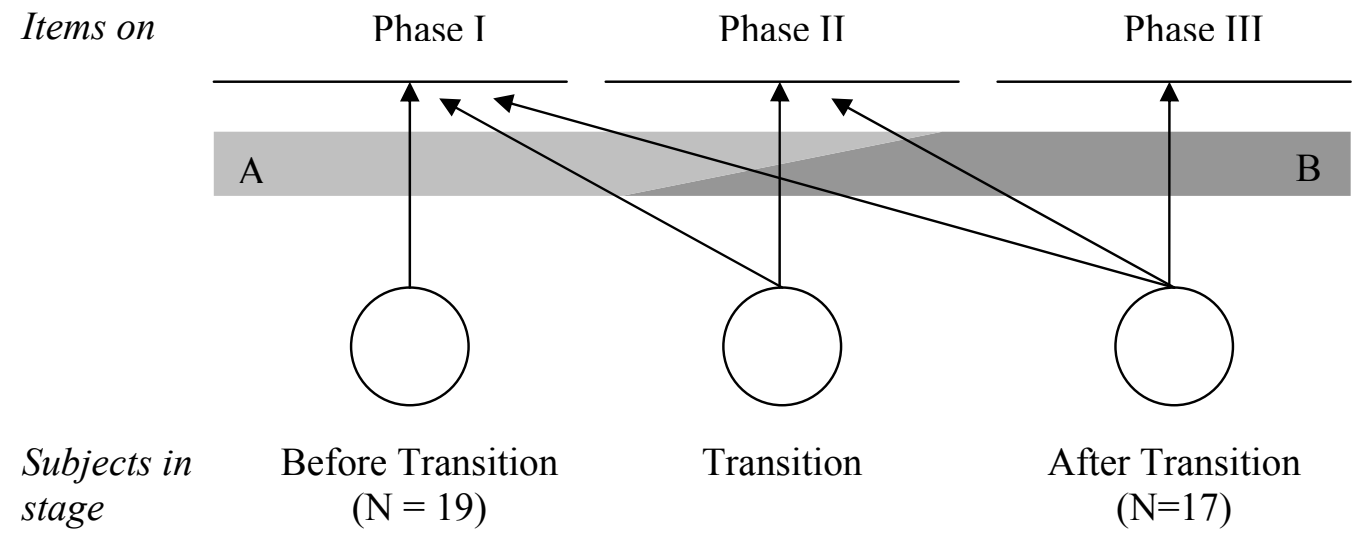

Figure 1: Design of the sample

Sample. A total of 73 employees involved in six OS projects carried out at 3 firms in the Netherlands were asked to participate. The response rates for the employees in these separate projects ranged from $34 \%$ to $80 \%$. In total 36 employees (49\%) were willing to participate. Of these employees 19 were at the Pre Phase (before Transition) and 17 at the Post Phase (after Transition); no employees could be found that were at the Transition Phase at the time of the data collection. The average age was 41 years, all employees except one were male.

Measures. Answers to the questions regarding the questions in the checklist were indicated on 5 point Likert scales. The categories of the importance scale were: (1) not at all important, (2) not important, (3) neither unimportant nor important, (4) important, (5) very important. The categories of the experience scale were: (1) not at all experienced, (2) not experienced, (3) neutral, (4) experienced, (5) very much experienced. Given the exploratory purpose of the study and the fact that items addressed different aspects of the OS process, the items were not scaled but answers were processed separately.

Results. Since there were two groups of employees with ratings of the Pre Phase we began with comparing their perceived importance and presence ratings. We performed a multivariate analysis of variance on the various items simultaneously. As the number of items was large compared to the number of subjects, we conducted separate analyses for the 
sections of the checklist. For the importance ratings the results of the multivariate tests were non-significant $(\alpha=.05)$. For the presence ratings a significant difference was found regarding the information items.

Table 3: Manova on Pre Phase ratings of subjects before $(N=19)$ and after Transition $(N=17)$. Multivariate tests for checklist sections.

\begin{tabular}{|l|c|c|c|c|}
\hline & Wilks Lambda & F & df & p \\
\hline Importance & & & & \\
- Information & .560 & 1.506 & $12-23$ & .192 \\
- Support & .768 & .871 & $9-26$ & .562 \\
- Procedure & .939 & .696 & $3-32$ & .561 \\
\hline Presence & & & & .028 \\
- Information & .433 & 2.506 & $12-23$ & .402 \\
- Support & .726 & 1.091 & $9-26$ & .072 \\
\hline
\end{tabular}

Univariate tests showed that the differences were limited to a few specific items. Thus, subjects in the Post Phase reported somewhat less honest information, less timely information, more use of a flow-chart describing the phases of the change, and more information on alternative suppliers. Because these differences were also small, we decided to base the further analysis of the Pre Phase data on the total sample.

\section{What do employees find important?}

We first present the results regarding the importance ratings with regard to the three phases of the outsourcing process. As items in the checklist were partly different for the distinct phases and for the role of the outsourcing organization and the service provider, it was decided to perform the analyses at the item level. That is, we identified the mean importance ratings given to the facets of the change process, as it took place with the outsourcing organization and the service provider. The (five) items with the highest perceived 
importance in each section of the checklist are presented in the tables below. Table 4 gives the results regarding the Pre Phase and the Transition Phase with the outsourcing organization (A), as well as the Transition Phase and the Post Phase at the service providing organization (B).

It appears from this table that certain facets remain important during the whole change process. For instance, honest, clear and correct information are found important in all phases. Likewise, great importance is assigned to support-related facets, such as respectful treatment and appreciation by the organization, and early signaling of and response to employee problems. These facets are not specific to outsourcing in any sense. They apply equally well to other types of organizational change. Other facets receive a different emphasis as employees move through the phases of the change process. In the Pre Phase much importance is assigned to consistent information and replies to questions raised in the new situation the employees find themselves in.

In the Transition Phase the emphasis shifts to information about job content, employment perspectives, and career opportunities. As for support, there is a shift from the possibility to talk about worries with the supervisor and the HR manager in the Pre Phase, to opportunity for coping, recognition of problems in group sessions, and personal input in development plans during the Transition and Post Phase. The most important procedural facets change as well. Initially a great importance is assigned to involvement of the labor unions and the Works Council, to a swift transition process, and to keeping promises. In the Transition Phase the correct transfer of labor terms and conditions becomes more salient, along with practical matters such as ID-cards, parking facilities, etc. In the Post Phase the emphasis shifts to facets relating to work and career, such as an exchange of information about new role expectations and further career paths. Moreover, in this phase much weight 
Table 4: Most important facets of change according to employees (Mean scores)

\begin{tabular}{|c|c|c|c|c|c|c|c|}
\hline \multicolumn{4}{|c|}{ OUTSOURCER } & \multicolumn{4}{|c|}{ SERVICE PROVIDER } \\
\hline \multirow{2}{*}{\multicolumn{2}{|c|}{$\begin{array}{c}\text { Pre Phase }(\mathrm{N}=36) \\
\text { Information }\end{array}$}} & \multicolumn{2}{|l|}{ Transition Phase $(\mathrm{N}=17)$} & \multicolumn{2}{|c|}{ Transition Phase $(\mathrm{N}=17)$} & \multicolumn{2}{|l|}{ Post Phase ( $\mathrm{N}=17)$} \\
\hline & & \multicolumn{2}{|l|}{ Information } & \multicolumn{2}{|l|}{ Information } & \multicolumn{2}{|l|}{ Information } \\
\hline 4. Honest information & 4,58 & 4. Honest information & 4,76 & 17. Honest information & 4,76 & 20. Clarity about future job content & 4,76 \\
\hline 12. Serious reply to questions & 4,53 & 1. Clear information & 4,65 & 20. Clarity about future job content & 4,76 & 16. Correct information & 4,71 \\
\hline 1. Clear information & 4,47 & 12. Serious reply to questions & 4,65 & 16. Correct information & 4,71 & 17. Honest information & 4,71 \\
\hline 3. Correct information & 4,44 & 3. Correct information & 4,59 & 19. Clarity about future employment & 4,65 & 14. Clear information & 4,65 \\
\hline 2. Consistent information & 4,39 & 2. Consistent information & 4,47 & 14. Clear information & 4,59 & 19. Clarity about future employment & 4,65 \\
\hline \multicolumn{2}{|l|}{ Support } & \multicolumn{2}{|l|}{ Support } & \multicolumn{2}{|l|}{$\begin{array}{r}\text { Support } \\
\end{array}$} & \multicolumn{2}{|l|}{$\begin{array}{c}\text { Support } \\
\end{array}$} \\
\hline 38. Respectful treatment & 4,61 & 37. Appreciation by employer & 4,53 & 42. Appreciation by employer & 4,53 & 42. Appreciation by employer & 4,53 \\
\hline 37. Appreciation by employer & 4,50 & $\begin{array}{l}\text { 30. Early signaling and response to } \\
\text { problems }\end{array}$ & 4,47 & 43. Respectful treatment & 4,53 & 43. Respectful treatment & 4,53 \\
\hline $\begin{array}{l}\text { 31. Talk about worries, wishes etc } \\
\text { with supervisor }\end{array}$ & 4,33 & 38. Respectful treatment & 4,47 & $\begin{array}{l}\text { 39. Early signaling and response to } \\
\text { problems }\end{array}$ & 4,41 & 29. Sufficient time for coping & 4,47 \\
\hline $\begin{array}{l}\text { 30. Early signaling and response to } \\
\text { problems }\end{array}$ & 4,31 & $\begin{array}{l}\text { 31. Talk about worries, wishes etc } \\
\text { with supervisor }\end{array}$ & 4,35 & $\begin{array}{l}\text { 41. Recognition of uncertainties in } \\
\text { group sessions }\end{array}$ & 4,35 & $\begin{array}{l}\text { 39. Early signaling and response to } \\
\text { problems }\end{array}$ & 4,29 \\
\hline $\begin{array}{l}\text { 32. Talk about worries, wishes etc } \\
\text { with HR manager }\end{array}$ & 4,17 & 29. Sufficient time for coping & 4,24 & $\begin{array}{l}\text { 40. Personal input in development } \\
\text { plan }\end{array}$ & 4,24 & 40. Personal input in development plan & 4,29 \\
\hline \multicolumn{2}{|l|}{ Procedure } & \multicolumn{2}{|l|}{ Procedure } & \multicolumn{2}{|l|}{$\begin{array}{c}\text { Procedure } \\
\end{array}$} & \multicolumn{2}{|l|}{$\begin{array}{c}\text { Procedure } \\
\end{array}$} \\
\hline 51. Promises are kept & 4,58 & 51. Promises are kept & 4,65 & 54. Promises are kept & 4,59 & 56. Honest transfer of contract terms & 4,71 \\
\hline $\begin{array}{l}\text { 53. Company-wide support for } \\
\text { decisions }\end{array}$ & 4,25 & $\begin{array}{l}\text { 53. Company-wide support for } \\
\text { decisions }\end{array}$ & 4,29 & 55. Honest transfer of contract terms & 4,29 & 54. Promises are kept & 4,65 \\
\hline 48. Works Council involvement & 4,17 & $\begin{array}{l}\text { 52. Management support for } \\
\text { decisions }\end{array}$ & 3,59 & 47. Union involvement & 4,29 & 55. Practical aspects well arranged & 4,41 \\
\hline 47. Union involvement & 4,08 & & & 48. Works Council involvement & 4,24 & $\begin{array}{l}\text { 49. Coordination A-B regarding } \\
\text { communication }\end{array}$ & 4,18 \\
\hline \multirow[t]{7}{*}{ 45. Not too long duration } & 3,81 & & & 50. Coordination A-B regarding work & 4,24 & 50. Coordination A-B regarding work & 4,18 \\
\hline & & & & & & \multicolumn{2}{|l|}{$\begin{array}{c}\text { Aftercare } \\
\end{array}$} \\
\hline & & & & & & 58. Contract terms maintained & 4,59 \\
\hline & & & & & & $\begin{array}{l}\text { 60. Exchange of expectations regarding } \\
\text { future in firm }\end{array}$ & 4,53 \\
\hline & & & & & & $\begin{array}{l}\text { 59. Exchange of expectations regarding } \\
\text { new job }\end{array}$ & 4,47 \\
\hline & & & & & & 61. Room for own input & 4,47 \\
\hline & & & & & & 62. Recognition of emotional aspects & 4,29 \\
\hline
\end{tabular}


$t$ is assigned to a good coordination between the former employer and the new employer with regard to communication and work content. Most of these facets are specific to outsourcing, as they relate to the unique nature of the change process that involves two organizations and combines challenges regarding job loss and exit with challenges of entry into a new organization and a new career episode.

\section{Perceived importance vs. presence}

Critical for a successful transition and for adaptation to the new situation is the degree to which the change process, as it takes shape in interplay between the two employing organizations, matches the employees' expectations. We have studied this issue by comparing the importance of change facets to their presence as perceived by the employees. The results are presented in the four figures on the next page. These figures display the perceived importance as well as the perceived presence, using the scales defined before. In an ideal case all facets rated as important would also be reported as present. However, as will be shown, discrepancies are the rule and a great number of important facets have been perceived lacking. Figures 2 and 3 give the results for the Pre Phase and the Transition Phase at the outsourcing organization. Figures 4 and 5 give the results for the Transition Phase and Post Phase at the service provider. The most noteworthy discrepancies agreements are mentioned in a legend.

It appears from these figures that employees experience major discrepancies between what they consider important and what they perceive as present in the change process. During the Pre Phase there are conspicuous gaps with regard to honest, clear, consistent, and correct information. The same is true for information regarding the necessity of outsourcing, the nature of the service providers, and the events to come (flowchart). For the Transition Phase the results are somewhat different. Initially, with the old employer, a lack of honest and regular information is reported, as well as a lack of information on what is going to happen. 


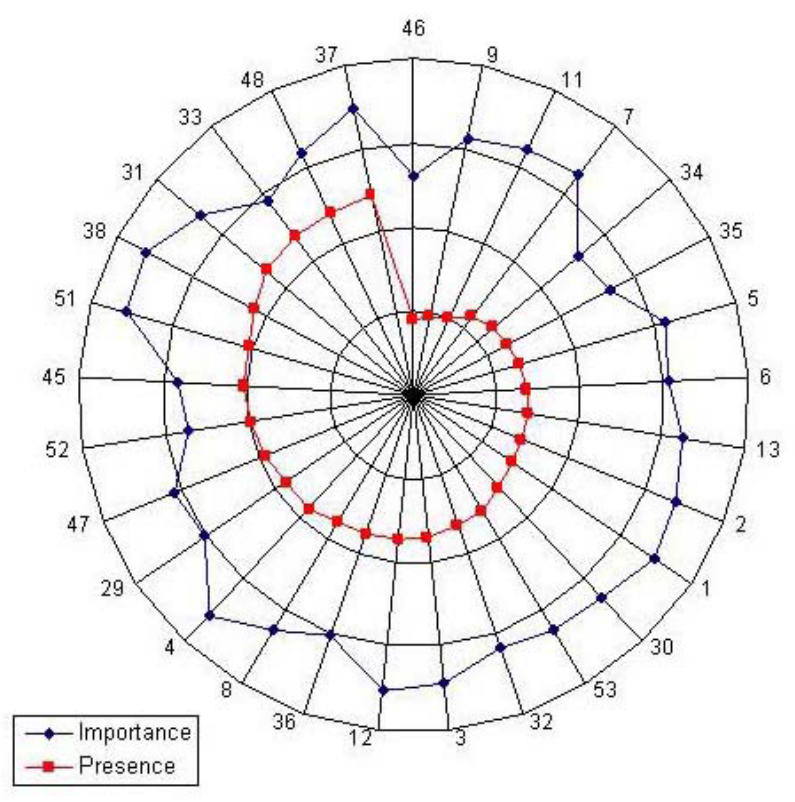

1

2

3

5

6

7

9

11

13
Discrepancies

Clear information

Consistent information

Correct information

Regular information

Information on jobs and people

Information on unavoidability

Information about providers

Flowchart

Timely information to apply

Early recognition and response to problems

Talk about problems with HR manager Opportunity for training before Opportunity for training during Personal influence

Company-wide support

Talk about problems with supervisor Support by colleagues Appreciation by employer Involvement of Works Council

Figure 2: Perceived Importance \& Presence

in Pre Phase (all Employees, $N=36$ )

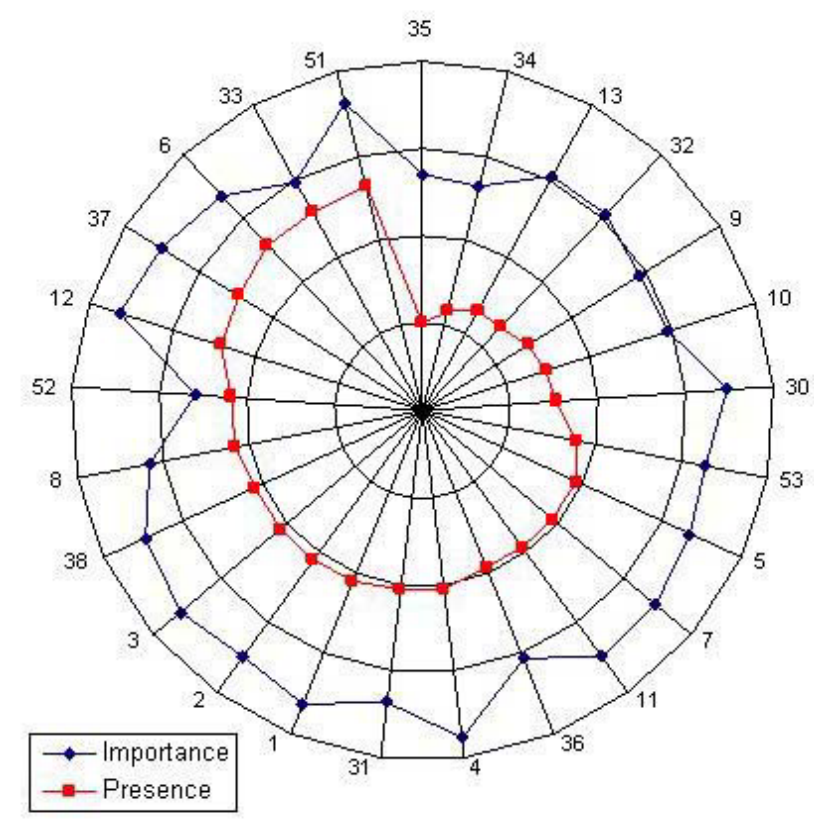

Figure 3: Perceived Importance \& Presence in

\section{Discrepancies}

Honest information

Regular information Information on unavoidability Information about providers Information on choice for provider Flowchart Timely information

Early recognition and response to problems Talk about problems with HR manager Opportunity for training before Opportunity for training during Recognition of problems in group sessions Company-wide support

Information on jobs and people

Reply to questions

Support by colleagues

Appreciation by employer

Promises were kept

Transition Phase (Employees after Transition; $N=17$ ) 


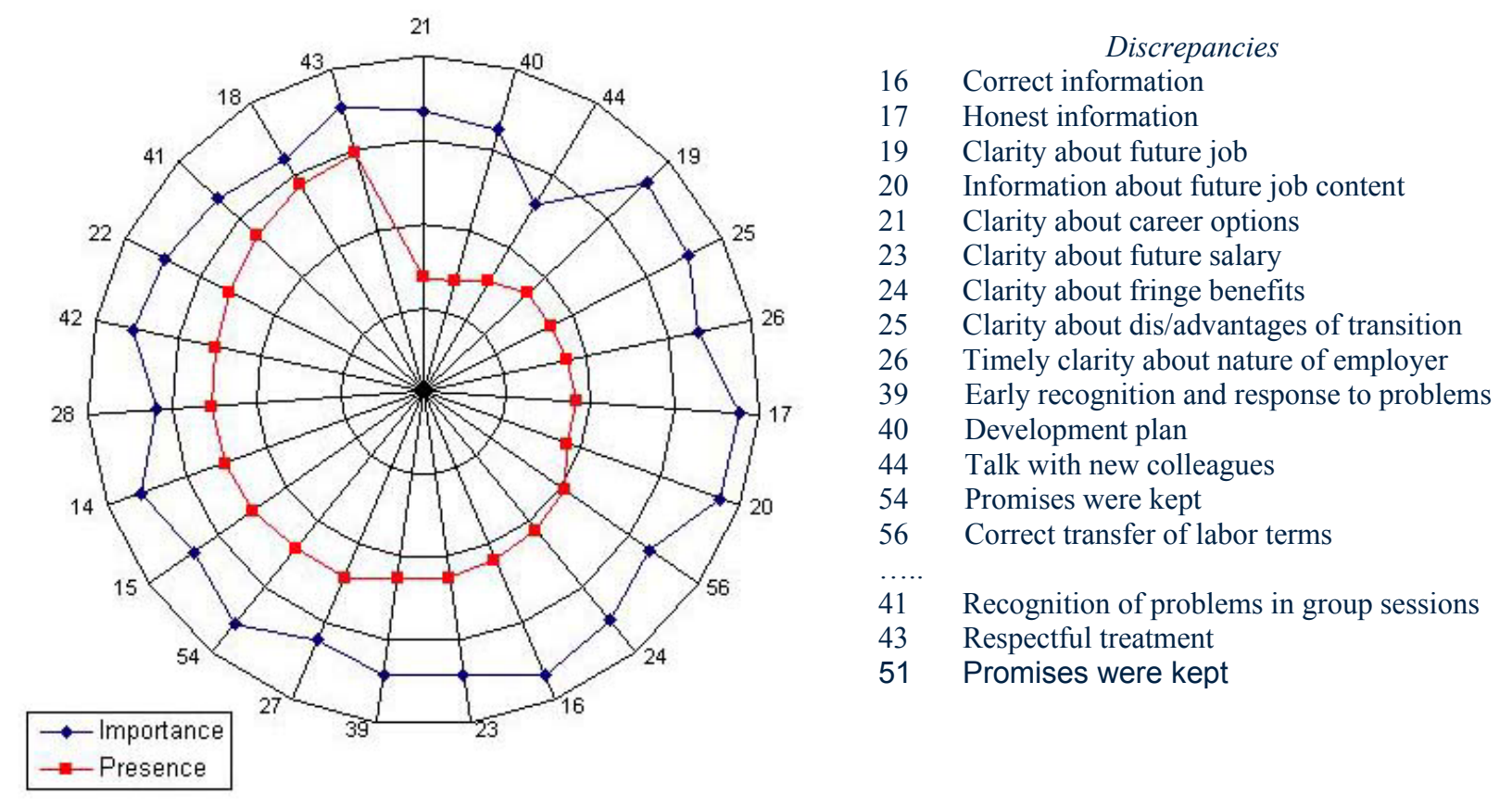

Figure 4: Perceived Importance \& Presence in Transition Phase (Employees after Transition; $N=17$ )

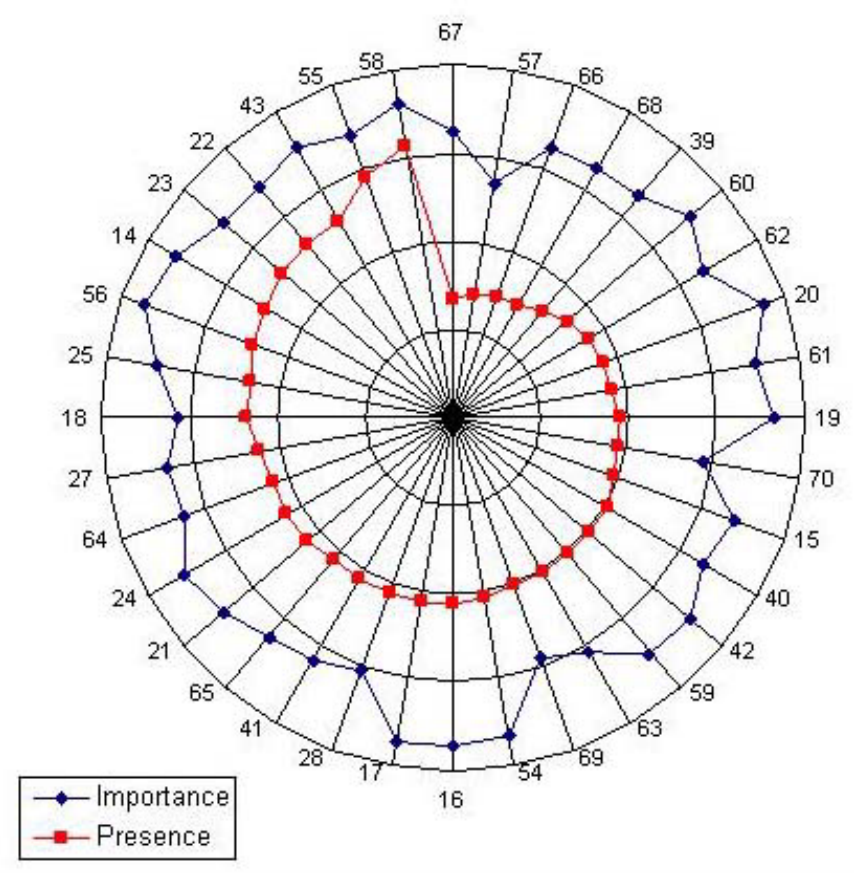

\begin{tabular}{ll} 
& \multicolumn{1}{c}{ Discrepancies } \\
54 & Promises were kept \\
57 & Support from previous employer \\
59 & Dialogue on new job \\
60 & Dialogue on future career \\
61 & Room for shaping new role \\
62 & Emotional aspects recognized \\
66 & Support in change towards service-oriented \\
& working \\
68 & Recognition of competences \\
15 & Consistent information \\
16 & Correct information \\
17 & Honest information \\
19 & Clarity about future job \\
20 & Information about future job content \\
39 & Early recognition and response to problems \\
40 & Development plan \\
42 & Appreciation \\
54 & Promises were kept (A) \\
$\ldots .$. & \\
43 & Respectful treatment \\
55 & Practical aspects of transfer \\
58 & Contract terms maintained
\end{tabular}

Figure 5: Perceived Importance \& Presence in Post Phase (Employees after Transition; $N=17$ ) 
At a later stage, the employees mention a lack of information regarding the new employer, the future career and the job content. As far as support is concerned, there appears to be a discrepancy with respect to the employer's early signaling of and response to problems, training opportunities, and acceptance by the new employer. For the Post Phase a number of other points stand out. Here, the main discrepancies relate to information about the job, a personal development plan, and earlier made promises. Facets relating to aftercare do also show gaps between actual practices and what employees find important, i.e. the recognition of competences by the new employer, support in personal profiling, support in acquiring a service-oriented work role, an exchange of expectations about the further career, and emotional support.

Some positive points can also be noted. Facets with a reasonable degree of agreement between what is found important and what is perceived to be present are: respectful treatment by both employers, appreciation, support by former colleagues, opportunities to talk with the supervisor about worries, wishes and opportunities, the recognition of personal problems in group sessions, and a low threshold in addressing the new employer.

\section{Discussion and practical implications}

The first question raised in this study is whether the organizational change process involved in outsourcing is comparable to that in mergers / acquisitions and downsizing. In this study we did not engage in an empirical comparison of outsourcing to mergers/acquisitions and downsizing, but looking at the implications of these strategies for employees, we are apt to conclude that outsourcing is different although there are obvious similarities as well. The change process in the case of outsourcing appears to be more complex and seemingly contradictory. On the one hand it forces employees to leave the organization they are part of and to give up their job, work role and identify; on the other hand it offers a new perspective of employment with another organization, other work roles and a different career perspective. 
This may produce a strong sense of ambivalence, not always seen in other organizational changes. The complexity of the change combined with its involuntary nature (Barger \& Kirby, 1995) may be a reason why the change management process as experienced by employees involved in outsourcing falls short of their expectations.

Looking at what employees find important we note a great need for information and a strong emphasis on issues of interactive and procedural justice. These are also the aspects in which shortcomings of actual practices are perceived. Some of the concerns voiced by the employees seem generic and common to all types of organizational change (Cummings \& Worley, 2001). Others reflect the uncertainties and worries raised by the particular phase of the change process they are going through, and are hence more specific for outsourcing. Considering that these uncertainties and worries are inherent in the very process of change, one may wonder to what degree the experience of gaps between the desirable and the actual may be prevented. Certain shortcomings regarding the information supply in the Pre Phase may be hard to avoid because of strategic reasons. The strategic interests which are at stake when exploring options for outsourcing and negotiating with potential service providers may preclude early communication with employees, even though they feel a need for it. On the other hand, it should be recognized that gaps perceived by employees - whether avoidable or not - may produce disappointments that can undermine the employees' motivation to perform and commitment to the new employer. A poorly managed change process carries the risk of suboptimal performance and poor service to the client organization, and can thereby add to the 'real costs' of outsourcing.

This study was exploratory and represents only a first step in charting the change implications of outsourcing. Further research will be needed to determine in which respects change management can be improved and how the overall effectiveness of outsourcing - in the eyes of the employees, the outsourcer and now client, and the service provider - can be enhanced. 
References

Allen, T. D., Freeman, D. M., Russell, J. E. A., Reizenstein, R. C., \& Rentz, J. O. (2001). Survivor reactions to organizational downsizing: Does time ease the pain? Journal of Occupational and Organizational Psychology, 74(2), 145-164.

Barger, N. J., \& Kirby, L. K. (1995). The challenge of changing in organizations: Helping employees thrive in te new frontier. Palo Alto: Davies-Black Publishing.

Benson, J. (1998). Dual commitment: Contract workers in Australian manufacturing enterprises. Journal of Management Studies, 35(3), 356.

Benson, J., \& Littler, C. (2002). Outsourcing and Workforce Reductions: An Empirical Study of Australian Organizations. Asia Pacific Business Review, 8(3), 16-30.

Carnal, C. A. (1990). Managing changes in organizations. Hempstead: Prentice Hall International.

Coyle Shapiro, J. A. M., \& Kessler, I. (2002). Contingent and non-contingent working in local government: contrasting psychological contracts. Public Administration, 80, 77101.

Cummings, T. G., \& Huse, E. F. (1989). Organization development and change (4th ed.). St. Paul: West Publishing.

Cummings, T. G., \& Worley, C. G. (2001). Essentials of organization development and change. Cincinatti: South-Western College Publishing.

Dawson, P. (1994). Organizational change: A processual approach. London: Paul Chapman.

Dempsey, M., \& McKevitt, D. (2001). Unison and the people side of mergers. Human Resource Management Journal, 11(2), 4-16.

DiMaggio, P. J., \& Powell, W. W. (1983). The iron cage revisited: Institutional isomorphism and collective rationality in organizational fields. American Sociological Review, 48(2), 147-160.

Doig, S. J., Ritter, R. C., Speckhals, K., \& Woolson, D. (2001). Has outsourcing gone too far? (Cover story). McKinsey Quarterly(4), 24.

Due, R. T. (1992). The real costs of outsourcing. Information Systems Management, 9(1), 78.

Elmuti, D., \& Kathawala, Y. (2000). The effects of global outsourcing strategies on participants' attitudes and organizational effectiveness. International Journal of Manpower, 21(2), 112-128.

Elmuti, D., Kathawala, Y., \& Monippalil, M. (1998). Outsourcing to gain a competitive advantage. Industrial management, 40(3), 20-25.

Gilley, K. M., Greer, C. R., \& Rasheed, A. A. (2004). Human resource outsourcing and organizational performance in manufacturing firms. Journal of Business Research, 57(3), 232.

Greer, C. R., Youngblood, S. A., \& Gray, D. A. (1999). Human resource management outsourcing: The make or buy decision. Academy of Management Executive, 13(3), 85.

Gupta, U. G., \& Gupta, A. (1992). Outsourcing the IS function. Information Systems Management, 9(3), 44-51.

Gutknecht, J. E., \& Keys, J. B. (1993). Mergers, acquisitions and takeovers: Maintaining morale of survivors and protecting employees. Academy of Management Executive, $7(3), 26$.

Hellriegel, D., Jackson, S. E., \& Slocum, J. W. J. (2002). Management: A Competency-Based Approach. Cincinnati, Ohio: South Western.

Kakabadse, A., \& Kakabadse, N. (2003). Outsourcing best practice: Transformational and transactional considerations. Knowledge and Process Management, 10(1), 60-71.

Kessler, I., Coyle-Shapiro, J., \& Purcell, J. (1999). Outsourcing and the employee perspective. Human Resource Management Journal, 9(2), 5-19. 
Khosrowpour, M., \& Subramanian, G. H. (1996). Managing information technology with outsourcing: An assessment of employee perceptions. Journal of Applied Business Research, 12(3), 85-97.

Lankford, W. M., \& Parsa, F. (1999). Outsourcing: a primer. Management Decision, 39(4), 310-316.

Legare, T. L. (1998). The Human Side of Mergers and Acquisitions., Human Resource Planning (Vol. 21, pp. 32-41): Human Resource Planning Society.

Lepak, D. P., \& Snell, S. A. (1999). The human resource architecture: toward a theory of human capital allocation and development. Academy of Management Review, 24(1), 31-48.

Logan, M. S., Faught, K., \& Ganster, D. C. (2004). Outsourcing a satisfied and committed workforce: a trucking industry case study. International Journal of Human Resource Management, 15(1), 147-162.

Loh, L., \& Venkatraman, N. (1992). Diffusion of Information Technology Outsourcing: Influence Sources and the Kodak Effect. . Information Systems Research, 3(4), 334358.

Mishra, A. K., \& Spreitzer, G. M. (1998). Explaining how survivors respond to downsizing: The roles of trust, empowerment, justice, and work redesign. Academy of Management Review, 23(3), 567-588.

Pearce, J. L. (1993). Toward an organizational behavior of contract laborers: Their psychological involvement and effects on employee co-workers. Academy of Management Journal, 36, 1082-1096.

Pinnington, A., \& Woolcock, P. (1997). The role of vendor companies in IS/IT outsourcing. International Journal of Information Management, 17(3), 199.

Van der Zee, J. T. M., Van Wijngaarden, J. R., Zeestraten, P. A. C., Pol, G. E., \& Vaessen, S. (1997). Succesvol outsourcen van IT in Nederland. Den Haag: Ten Hagen \& Stam Uitgevers.

Van der Zee, J. T. M. (Ed.). (1999). Strategic sourcing and partnerships: Challenging scenariosfor IT alliances in the network era. Amsterdam: Addison Wesley Longman.

Walker, R., \& Walker, B. (2000). Privatisation: Sell off or sell out. The Australian experience. Sydney: ABC Books. 